\title{
Reflections on the Reflection Paper on the Future of EU Finances
}

\section{Rob Ackrill}

\section{Introduction: The Reflection Paper on the Future of EU Finances}

In March 2017, shortly before the $60^{\text {th }}$ Anniversary of the signing of the Treaty of Rome, a White Paper was published which reflected on the challenges countries face and which sought to chart a course for the EU27 to 2025 (and beyond). ${ }^{1}$ In his introduction to the White Paper, Jean-Claude Juncker argued: 'As we decide which way to go, we should remember that Europe has always been at its best when we are united, bold and confident that we can shape our future together.' The White Paper set out five illustrative 'ways to go', ranging from doing less, carrying on as now, letting some countries go further, through to the EU27 doing more together.

Since then, the European Commission has published five Reflection Papers. Three focused on specific policy areas: Economic and Monetary Union (EMU), defence and the social dimension of EU activity. One looked at how the EU could make the most of the opportunities afforded by globalisation. We focus here on the fifth and final one, the Reflection Paper on the Future of EU Finances (hereafter the 'Reflection Paper'). It is fitting that this paper was published last. By exploring the budgetary implications of the five scenarios, it focuses on an aspect of the EU that not only facilitates EU policy activity, but which can represent a binding constraint on it as well - economically and politically.

For despite the fine sentiments of Mr Juncker, which I broadly agree with, when it comes to the EU Budget the member states are less 'united bold and confident', more selfish, petty and truculent. If 'academic politics is the most vicious and bitter form of politics, because the stakes are so low', I would argue that debates around the EU Budget come a close second. EU spending of $€ 150$ billion or so each year is, in round numbers, under 1 per cent of EU Gross Domestic Product; whereas EU countries' national budgets are typically over 40 per cent of national GDP).

Yet debates over the EU Budget have been, repeatedly, a flashpoint for national squabbling. Rather than being simply the fiscal means to collective policy ends, it has taken on the identity of a separate EU policy in its own right. At the heart of this is countries' net transfers into and out of the EU Budget - regardless of how reductive such as debate is in terms of the value of EU membership to countries. As a result this approach from member state governments has 
repeatedly nullified efforts to debate meaningfully serious changes to EU Budget funding and expenditures. This is what the latest contribution to this debate, the Reflection Paper, is up against. Does that mean it is doomed to failure? I would say yes and no. Change will have to come - but whether that constitutes success or failure depends on how you define these terms.

\section{Change Must Come}

Why change will have to come is simple: Brexit. The UK is one of the largest gross and net contributors to the EU Budget. In 2015 those figures were, respectively, $€ 21.4 \mathrm{bn}$ and $€ 14 \mathrm{bn}$ (at current, 2017, exchange rates, about $£ 18$.8bn and $£ 12.3 \mathrm{bn})$. Even though these figures were much higher in 2015 than any previous year, Brexit - as the Reflection Paper notes - represents a challenge on the revenue side. In terms of spending, the review considers refocusing the EU Budget on new policy priorities which, currently, are (just about) accommodated by the flexibility of the current seven year Multiannual Financial Framework (MFF). These include 'migration management, internal and external security, external border control, the fight against terrorism and defence'. ${ }^{2}$

We look in more detail later at the possible changes to EU Budget revenue sources and policies to be funded. But why might things remain the same? Treating the EU Budget as an EU policy in its own right has resulted in stability in the distribution of EU Budget transfers across member states over time, regardless of the needs of different policy agendas. Like a multi-team match of tug-of-war, each country is pulling in a different direction as it tries to hold on to what it has already. As a result, the big knot in the middle moves very little.

It was not always like this. In the early years, with the EU Budget growing in nominal terms, especially as spending grew on the Common Agricultural Policy (CAP), member states' shares mattered little. From the mid-1980s, however, as the growth in CAP spending put pressure on the EU Budget overall, reforms were introduced to try to curtail spending growth. From this point, distribution began to matter a great deal. This had perhaps its greatest expression in the 1992 CAP reform. Despite the magnitude of the changes to individual policy instruments, there was remarkably little change to the distribution of explicit and implicit CAP-related fiscal transfers across countries. ${ }^{3}$ When the EU was last faced with an event that represented a critical juncture in its budget policy, the 2004 enlargement, it managed to devise a deal that delayed and restricted the redistributive effects of, in particular, the direct aid payments under the CAP. 
Thus whilst Brexit represents a critical juncture for the EU Budget, and a window of opportunity for those seeking to redistribute and redefine what the EU Budget is, does and how it does it, history suggests we should not expect much.

\section{What Does the Reflection Paper on EU Finances Propose?}

The Reflection Paper analyses possible EU Budget futures for each of the five scenarios for the EU in the White Paper. Table 1 summarises their different policy priorities. ${ }^{4}$

Table 1: Five Scenarios for the Future of EU Finances - Policy Priorities

\begin{tabular}{|c|c|c|c|c|}
\hline 1 & 2 & 3 & 4 & 5 \\
\hline Carrying On & $\begin{array}{l}\text { Doing less } \\
\text { together }\end{array}$ & $\begin{array}{c}\text { Those who want } \\
\text { more do more }\end{array}$ & Radical redesign & $\begin{array}{c}\text { Doing much more } \\
\text { together }\end{array}$ \\
\hline $\begin{array}{l}\text { Take forward } \\
\text { current reform } \\
\text { agenda }\end{array}$ & $\begin{array}{l}\text { Mainly financing } \\
\text { of functions needed } \\
\text { for the single } \\
\text { market }\end{array}$ & $\begin{array}{l}\text { As in Scenario 1, } \\
\text { with additional } \\
\text { money made } \\
\text { available by some } \\
\text { member states for } \\
\text { the areas where } \\
\text { they decide to do } \\
\text { more }\end{array}$ & $\begin{array}{l}\text { Financing of } \\
\text { priorities with very } \\
\text { high EU value } \\
\text { added }\end{array}$ & $\begin{array}{l}\text { Doing much more } \\
\text { across policy areas }\end{array}$ \\
\hline
\end{tabular}

\section{The Reflection Paper and EU Budget Revenues}

On the revenue side, all five scenarios foresee the ending of all rebates and adjustments currently in place. Since 1984, a time when the UK was one of the poorest member states making one of the largest net contributions, a formal mechanism has reduced its net contribution to the EU Budget. This mechanism, reformed on several occasions, is still in operation. The cost of the rebate is borne by all member states, but currently reductions on these contributions are in place for Denmark, Germany, the Netherlands, Austria and Sweden - at a further cost to the remaining member states. ${ }^{5}$

Only Scenario 2 speaks of not introducing new sources of revenue. This would appear more appropriate for Scenario 1, although since each scenario is built from multiple elements that are not mutually dependent, it would be wrong to read much into this. The revenue proposal under Scenario 4 is interesting. It builds on Scenarios 1-3, which include removing all rebates, 
but also proposes reform or abolition of the VAT-based own resource. This would represent a simplification over current procedures.

There are several arguments in support of this proposal. First, VAT is a regressive tax, thus a limit is placed on the size of the VAT base on which the VAT call-up rate is applied (the percentage of the VAT-base that member states pay over to the EU Budget). Second, the callup rate has been reduced over time and, with it, the share of VAT in the total revenues of the EU Budget. Third, VAT is the means by which several other budget rebates are made. Given ongoing concerns over the distributive implications of VAT per se, the planned removal of all budget adjustments, and the decreasing importance of VAT as a source of revenue, the time has indeed come to consider its future.

Scenario 4, like most scenarios, proposes new sources of revenue. Although the Reflection Paper does not provide much detail, current thinking is directed towards possible sources of revenue linked to EU policies and policy priorities. Examples include a Financial Transaction Tax, green taxes, revenue from a common consolidated corporate tax base, or EMU-related seigniorage revenues. Any new revenue source should reflect a series of ideal attributes, including transparency, simplicity, stability, equity across member states and consistency with Union policy objectives. ${ }^{6}$ As I have argued previously ${ }^{7}$, a system dominated by direct payments from the member states satisfies most of these ambitions. One exception is that of Union policy objectives. Although not mentioned in the Reflection Paper, previous attempts to introduce new revenue sources have sought to give the EU greater financial independence from the member states. That is something the member states have never been willing to grant.

\section{The Reflection Paper and EU Expenditures}

The range of options for EU policy activism is, inevitably, reflected in their budgetary consequences. Scenario 1 foresees a 'broadly stable' evolution of budget spending, but with some redistribution between policy areas. This occurs, notably, in a shift from cohesion and agriculture to security, defence, migration and external actions. Scenario 3 is broadly the same, except insofar as 'enhanced cooperation' activities result in higher expenditure, paid for by the participating member states. Scenario 5 sees more of everything. This includes more spending, in absolute terms, on agriculture, which would reverse the trend of at least a decade. 
Scenarios 3 and 5 share the ambition of providing a macroeconomic stabilisation function for EMU. With Scenario 5, this is expressed as a 'fully-fledged euro area budget and European Monetary Fund' ${ }^{8}$ The practical problems with this, however, cannot be overstated. For at least 40 years it has been recognised that for the EU Budget to take on a macroeconomic stabilisation role effectively, it will have to be much larger - perhaps 7-10 per cent of GDP, rather than the 1 per cent or so it has been for decades. Moreover, it would require a Treaty change: the EU Budget is subject to an annual balanced budget rule, which is inimical to the requirements of macroeconomic stabilisation. EMU requires further fiscal policy coordination - but I remain unconvinced that the EU Budget is the appropriate vehicle. ${ }^{9}$

This leaves Scenarios 2 and 4, both of which offer visions of a smaller EU Budget, supporting more limited EU-level policy activism. Scenario 2 is arguably the most radical in terms of the future of the EU, as it implies focusing primarily on the Single European Market. Further, the White Paper adds that the 'free movement of people and services not fully guaranteed' ${ }^{10}$ Thus Scenario 2 implies rolling back even on the current commitment to the Four Freedoms of the Single European Market.

Scenario 2 is described in the White Paper as 'Nothing but the Single Market'. In practice, however, current areas of activity for the EU Budget continue more or less as before, albeit at lower levels (of absolute spending). This includes the two main policy areas of agriculture and cohesion. Spending on competitiveness would fall in absolute terms, but take a greater share of the total. Of the newer areas of spending, foreign policy and defence would see spending fall, with no spending on Schengen migration and security measures. Instead, spending would be based on bilateral engagement. Given recent events around security and migration, it will be interesting to see how the member states might try to square the circle of expressing concern over these issues, without spending anything collectively on them.

This leaves Scenario 4, described in the White Paper as 'Doing Less More Efficiently', but called 'Radical Redesign' in the Reflection Paper. That said, the limited information provided in the Reflection Paper is confused. Total spending is expected to fall, to be focused on the 'financing of priorities with very high EU value added'. ${ }^{11}$ That said, spending is to be enhanced on security, defence, migration and external actions, with spending on agriculture and cohesion merely taking a 'lower share' of the total, in contrast to the 'lower amount' under Scenario 2. So, somehow, absolute spending is to be maintained on the last two policy areas, a higher share 
is to go to the newer policy areas, meaning a higher absolute spend, yet spending overall is to fall. Elsewhere in the Reflection Paper, however, it is implied that spending on agriculture and cohesion will fall in absolute terms. Proposals for agriculture include reduced direct payments, and a focus primarily on farmers facing particular constraints (small farms, mountainous terrain, etc), whilst changes to cohesion would see payments to richer regions removed. In other words the EU Budget would still have essentially the same headline policies, but specific elements within each would see spending reduced or removed.

\section{Plus ça change, plus c'est la même chose?}

These five scenarios - and their individual components - are a basis for discussion, not a closed list from which one must be chosen. They cover a wide range of potential issues on the spending side: from no change, less of everything, enhanced cooperation in some areas, more of some and less of others, through to more of everything. On the revenue side, there are two features that stand out. The first is the (perpetual) ambition to introduce new sources of revenue, in particular linked to specific EU policies. The second is the fact that, for once, the status quo on revenues is not an option. Brexit does not require changes to the range of policies funded through the EU Budget - although it does offer a great opportunity for reflection on what the EU could and should be engaged in. On the revenue side, however, change shall come. Losing one of the largest contributors to the EU Budget will have an impact but, more important than this, Brexit means the end of the UK rebate and, with it, the other adjustments attached to it.

Looking to possible directions for discussions over the next 12-18 months, on the revenue side I would expect the VAT-based revenue either to be retained at its current low rate, or removed altogether. The Gross National Income-based revenue has, over time, grown in relative and absolute importance - and I would expect that to continue. As for new revenue sources, I see little prospect of these being negotiated within the timeframe set by the Reflection Paper. They would reintroduce complexity and ambiguity just as the end of the rebates (and possibly of VAT) would bring simplification. Moreover, typically they are tied to policies that are either still in their infancy or, notably with EMU-related options, relevant currently only to some member states.

On spending, the UK was repeatedly a leading voice in favour of CAP reform. It is hard to see how pro-CAP reform interests within the Council would increase influence as a result of Brexit. In the face of the loss of a major contributor the poorer member states, who receive the most 
from cohesion spending, will likely redouble their efforts to maintain spending, in the name of economic and social cohesion. Competitiveness is at the heart of Europe 2020, but budgetarilyspeaking has always been the poor relative to cohesion. As for the newer areas of policy activism, I strongly suspect that the emphasis on greater budgetary flexibility will be crucial here. Rather than providing new resources for external action, security, defence and migration, I would anticipate budgeted spending to be kept largely unchanged - but with greater margins being built into a fundamentally-unchanged EU Budget structure, to accommodate unpredictable spending on, for example, security and migration/refugee crises.

As I noted at the outset, the politics around the EU Budget have been typified by the dominance of national interests. Brexit may have shifted political awareness of the benefits of EU membership, leading to greater, albeit fragile, unity around the 'EU project'. That has never been enough previously, however, to shape negotiations over the EU Budget. Previous experience also suggests that, even when proposals are made for increased spending on 'new' policy areas, the end result of negotiations is the preservation of spending on the principal current policies, with new measures being squeezed out. ${ }^{12}$ I therefore expect that negotiations will be dominated by countries seeking to preserve the status quo as far as possible, given Brexit. As for the new policy areas on the table, they may be thrown a few scraps, but only as a residual, once the main policy areas - and the principal recipients - have been sated.

Plus ça change indeed.

\section{Rob Ackrill}

Professor of European Economics and Policy

Department of Economics, Nottingham Business School, Nottingham Trent University

\footnotetext{
${ }^{1}$ European Commission (2017) White Paper of the Future of Europe: Reflections and scenarios for the EU27 by 2025. This and the five related Reflection Papers, including the Reflection Paper on EU Finances, are all available from: https://ec.europa.eu/commission/white-paper-future-europe-reflections-and-scenarios-eu27_en

${ }^{2}$ Reflection Paper, page 21.

${ }^{3}$ For the EU Budget overall see, inter alia, Ackrill, R.W. and Kay, A. (2006a) Historical Institutionalist Perspectives on the Development of the EU Budget System. Journal of European Public Policy, 13(1), 113-133. For the CAP see, inter alia, Ackrill, R.W. (2005) Common Agricultural Policy. In: van der Hoek, P. ed. Handbook of Public Administration and Policy in the European Union. Boca Raton: CRC Press, 435-487. For a detailed
} 
analysis of the 1992 CAP reform, see Ackrill, R.W., Hine, R.C., Rayner, A.J. and Suardi. M. (1997) Member States and the Preferential Trade and Budget Effects of the 1992 CAP Reform: A Note. Journal of Agricultural Economics, 48(1), 93-100.

${ }^{4}$ For further details, see the Annex Table in the Reflection Paper, page 38.

${ }^{5}$ For details, see the European Parliament Research Service's 2016 Briefing (PE 577.973) on "The UK "rebate" on the EU Budget: An explanation of the abatement and other correction mechanisms', especially page 6: http://www.europarl.europa.eu/RegData/etudes/BRIE/2016/577973/EPRS BRI(2016)577973_EN.pdf (last accessed 25 July 2017).

${ }^{6}$ Reflection Paper, page 29.

${ }^{7}$ House of Lords (2007) Funding the European Union: Report with evidence. HL Paper 64, $12^{\text {th }}$ Report of Session by the House of Lords European Union Committee. See in particular pages 1-4 of the Minutes of Evidence.

${ }^{8}$ Reflection Paper, page 35.

${ }^{9}$ Ackrill, R. (2003) Stabilisation in EMU - A Critical Review. In: Baimbridge, M. and Whyman P., eds Fiscal Federalism and European Economic Integration. London: Routledge, 103-118.

${ }^{10}$ White Paper, page 29.

${ }^{11}$ Reflection Paper, page 38.

${ }^{12}$ Kay, A. and Ackrill, R. (2007) Financing social and cohesion policy in an enlarged EU: plus ça change, plus c'est la même chose? Journal of European Social Policy, 17(4), 361-374. 